International Journal of Physical Sciences and Engineering
Available online at www.sciencescholar.us
Vol. 4 No. 1, April 2020, pages: $21-28$
e-ISSN : 2550-6943, p-ISSN : 2550-6951
https://doi.org/10.29332/ijpse.v4n1.416

\title{
Obtaining Biogas Product from Biological Residues Vaccines in Chone City
}

\author{
(1) crossmark \\ Janner Leonel Santos Mantuano a, Manuel Enrique Vergara Macías b, \\ Erik Sebastian Sanchez Toapanta c, Klever Steven Tubay Palma d, María Fernanda Vivas Giraldo e
}

Manuscript submitted: 09 January 2020, Manuscript revised: 18 February 2020, Accepted for publication: 27 March 2010

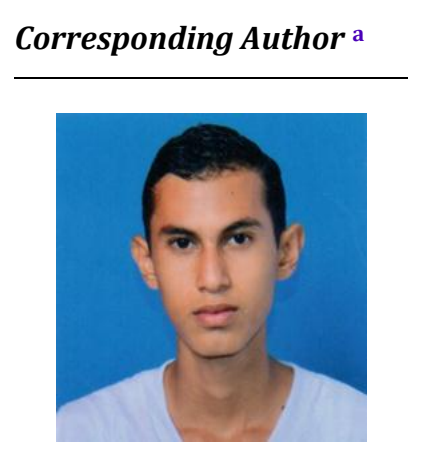

\section{Keywords}

anaerobic fermentation;

biodigester;

biogas;

biological wastes;

renewable energy;

\begin{abstract}
In this research, we studied the use of cattle biological waste to obtain biogas through a biodigester in the city of Chone, considered the livestock capital of Ecuador. Biogas is a mixed gas produced by the fermentation (anaerobic digestion) of organic materials in the absence of oxygen. It is mostly composed of methane and carbon dioxide. The biogas production process takes place in a container called a digester, in which the anaerobic fermentation process occurs. Obtaining biogas is one of the most used alternative sources for the production of renewable energy, so it can be evidenced by its importance as a tool against the fight of the environmental problem that exists today. The use of biogas of bovine origin has a high calorific value so it can be used for the production of heat, electricity or biofuel. This initiative seeks to manage and sustainably reduce organic waste, reduce the amount of greenhouse gas emitted into the atmosphere and reduce dependence on fossil fuels.
\end{abstract}

International Journal of Physical Sciences and Engineering (C) 2020. This is an open access article under the CC BY-NC-ND license (https://creativecommons.org/licenses/by-nc-nd/4.0/).

\section{Contents}

Abstract

1 Introduction

2 Materials and Methods

3 Results and Discussion

4 Conclusion Acknowledgments

References

a Universidad Técnica de Manabí, Portoviejo, Ecuador

b Universidad Técnica de Manabí, Portoviejo, Ecuador

c Universidad Técnica de Manabí, Portoviejo, Ecuador

d Universidad Técnica de Manabí, Portoviejo, Ecuador

e Universidad Técnica de Manabí, Portoviejo, Ecuador 


\section{Introduction}

The boom in the demand for energy consumption across the planet and the dependence of human beings on non-energy sources Renewable, as well as the associated environmental problems, requires us to search for new technologies and energy sources. The main environmental problems at present are related to the negative impacts generated through agricultural and livestock activities. The livestock sector is one of the main productive sectors of Ecuador, this activity generates a high quality of waste that does not have adequate management or final disposal, affecting natural resources such as water, soil, and air (Cadavid \& Bolaños, 2015).

The use of technologies for obtaining biogas for energy purposes dates back to past centuries. In some places of the planet, it is used as a tool against the fight of the existing environmental problem, biogas technology contributes to the generation of economic income and savings in production costs (Díaz, 2013). As raw material for this process, the excreta of poultry, pig manure, cow, kitchen waste, grass and organic matter, in general, can be used. Some factors limit the production of biogas, such as the winter season, economic costs and the life of the digester. Anaerobic digestion of animal manure, in this case, beef, has the general objective of converting organic waste into biogas, which is a renewable fuel that can be used to produce electricity or heat (Castillo, 2013).

The development of this technology has social, economic, cultural and especially environmental impacts. The production and use of biogas drive regional development and consequently the generation of employment (El-Ghonemy, 2012; Al Malki et al., 1998; Koroneos et al., 2003). It allows people who bury these types of technologies to innovate, motivated to work in processes of producing clean energy to achieve food and energy sovereignty with enrichment of renewable resources. As for farmers, obtaining biogas through organic waste has several benefits, for example, savings for fertilizer and energy producers, but also increase the productivity of their crops, which directly improves the feeding families without damaging the soil and for those who sell these products also represent extra income and local sources of employment (Durazno, 2018; Jiménez, 2019; Martínez, 2015).

This benefit makes it possible for producers to increase their income while being part of a natural cycle where waste from one system is used to be part of another, and even better, expanding benefits in their community. The results of a biodigester for obtaining biogas have a direct impact on the lives of users, in turn reducing greenhouse gases from agriculture and livestock (Paez, 2016; Rodriguez et al., 2016). When organic wastes are introduced to the biodigester, gases are captured to produce energy, preventing them from decomposing in the open air and accumulating in the atmosphere, increasing the temperature of the earth.

\section{Materials and Methods}

This paper analyzes the process of obtaining biogas from anaerobic biodigestion of cattle biological waste in the city of Chone. Additionally, biodigestion residues are evaluated as a possible agricultural fertilizer (Sumathi et al., 2005; Naundorf et al., 1985). To carry out this research, a large amount of information was collected, which was based on several reliable documents from recognized web pages and with the help of some texts provided in web libraries, and attached help and recommendations from our tutor and some Engineers Agronomist of the Polytechnic School of Agriculture of Manabí (ESPAM MFL).

The Inductive-deductive method was used based on the observation and research techniques for the collection of data and information, which is presented in this work through texts and images that detail the most relevant points of this research and annexing the specific concepts, which are very important to facilitate the understanding of the subject (Serna et al., 2011; Vera et al., 2014). To talk about biogas, it is very important to know what biogas is, how it is obtained, what factors influence its obtaining and what are its utilities and benefits. Obtaining the biogas will depend on the resources and conditions in which it is located in the place where it will be carried out, which is why knowing the location is very important. 


\section{Results and Discussions}

\section{Basic concepts}

Biogas. The gas obtained from the decomposition of organic waste by anaerobic means (without oxygen). This process is developed by bacteria.

Biodigester. The container is known as a reactor, in which the organic substances to be fermented are stored. It is where the biochemical process of anaerobic fermentation takes place.

Description of the photovoltaic systems

\section{The geographical location of the research site}

Chone, also known as San Cayetano de Chone, is an Ecuadorian city, cantonal head of the Chone Canton. It is located in the north-central part of the coastal region of Ecuador "north of the Province of Manabí" (Macías, 2019). Considered the livestock capital of Ecuador. The geographical location of the Chone Canton is shown in Figure 1.

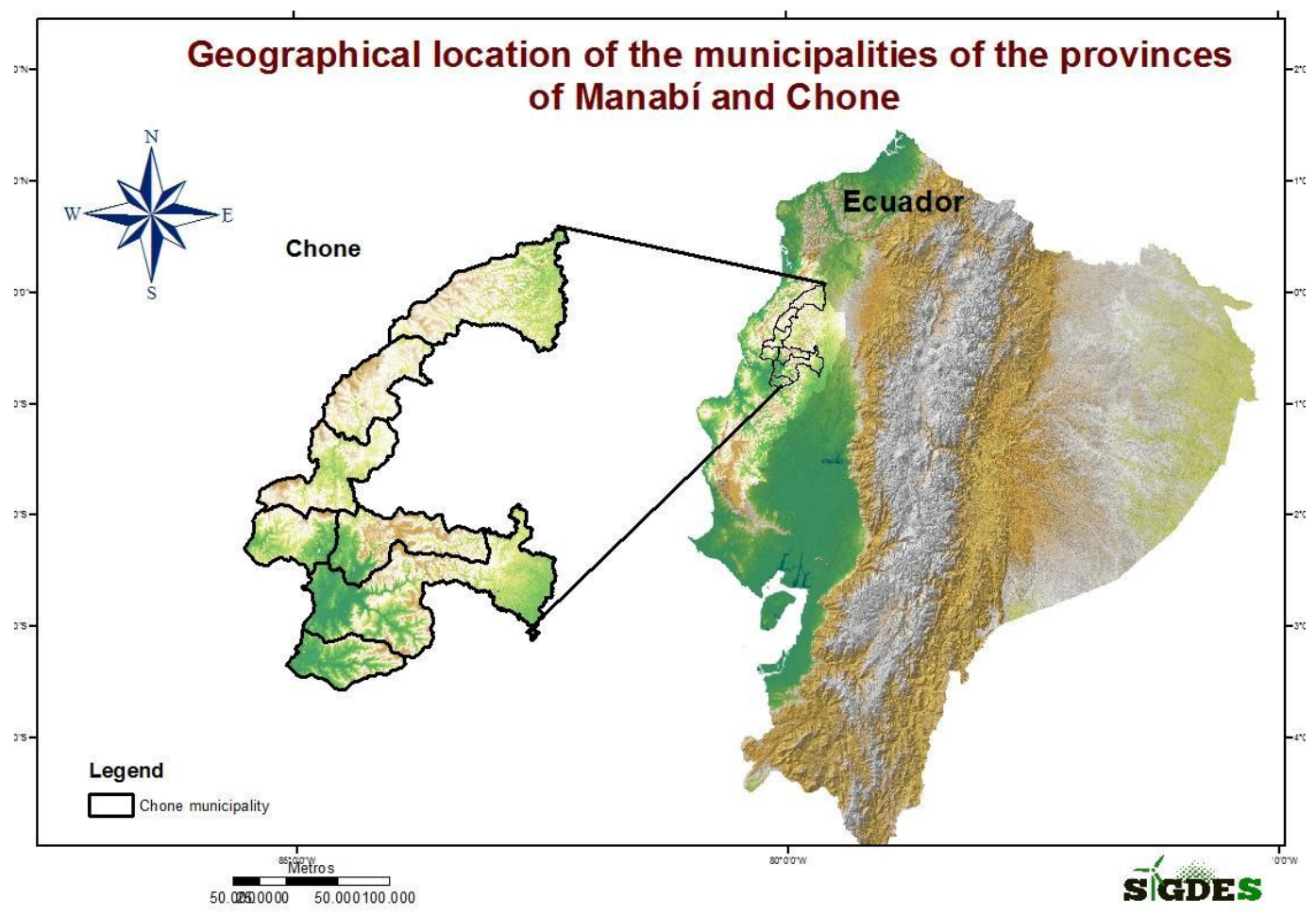

Figure 1. Location of Canton Chone Source: (Rodriguez et al., 2016)

\section{Process and use of the Biodigester}

A biodigester (digester), in its simplest form, is a closed, hermetic and impermeable container (Castillo, 2013). Within this, the organic material to be fermented (such as animal and human feces, plant waste) is deposited, in a certain dilution of water so that through anaerobic fermentation, methane gas and organic fertilizers rich in nitrogen, phosphorus, and potassium are produced, and, also, the contaminating potential of excrement is diminished. Figure 2 shows the biogas production process for obtaining electrical and thermal energy.

\footnotetext{
Mantuano, J. L. S., Macías, M. E. V., Toapanta, E. S. S., Palma, K. S. T., \& Giraldo, M. F. V. (2020). Obtaining biogas product from biological residues vaccines in Chone city. International Journal of Physical Sciences and Engineering, 4(1), 21-28. https://doi.org/10.29332/ijpse.v4n1.416
} 


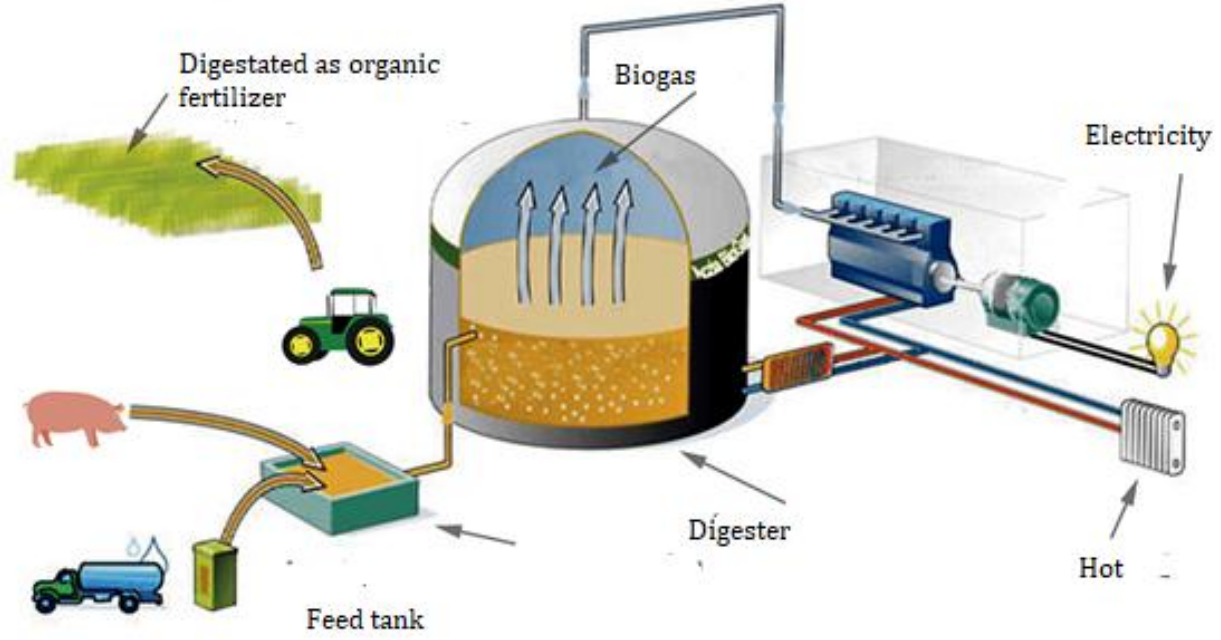

Figure 2. Process and use of the Biodigester to obtain Biogas

Source: (Portillo, 2017)

The production of biogas is a natural process that occurs in an anaerobic environment, that is, lacking oxygen and depends mainly on variables such as $\mathrm{pH}$, temperature, retention time, among others.

\section{Description of the process for obtaining biogas biogas}

The production process takes place in a container called a digester or biodigester, in which the anaerobic fermentation process occurs, while biogas uptake occurs through a bell, from which Extracts gas through a pipe or hose line (Sharma et al., 1988: Sitorus \& Panjaitan 2013; Garba, 1996). In the anaerobic biodigester the biochemical process by which matter is transformed into biogas is made up of four well-defined stages: hydrolysis, acidogenesis, acetogenesis, and methanogenesis, in which specific groups of microorganisms that successively digest the compounds generated in the stages are involved previous (Castillo, 2013).

The bacterial population responsible for the transformation process is shown in Figure 3.

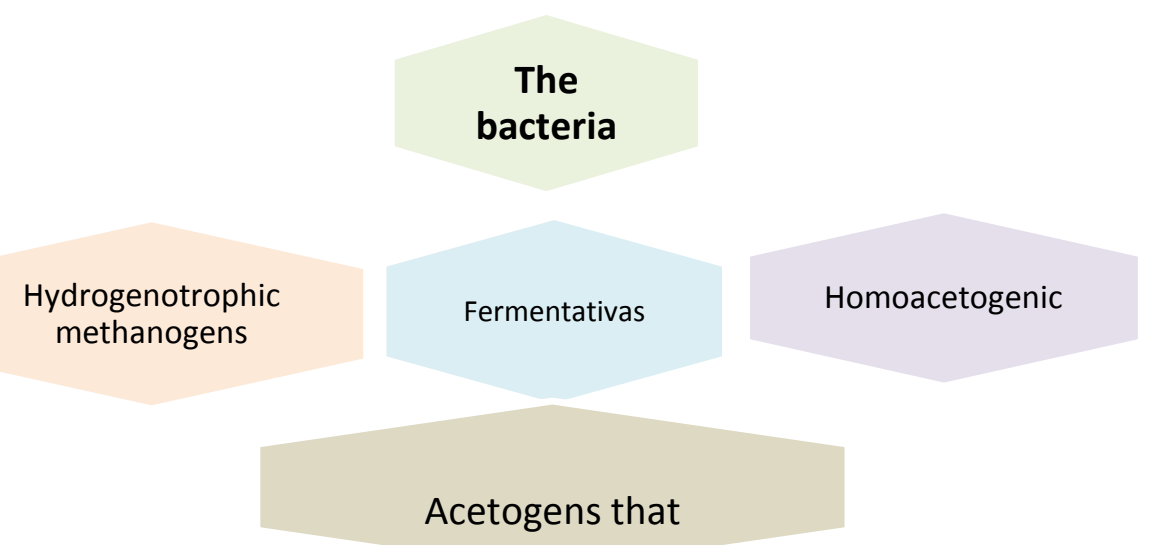

Figure 3. Bacteria involved in the process 
Stages of the transformation process

Hydrolysis: It is the first stage of biogas production and requires that organic compounds cross the cell wall so that their organic matter can be harnessed (López et al., 2017). The time it takes for the entire process is largely determined by this stage, whose success is linked to the dimensions of the particles, the temperature, the biochemical composition of the substrate and the $\mathrm{pH}$, among more factors;

Acidogenesis: At this stage the conversion of soluble organic molecules into three types of compounds takes place. They are divided into those that cannot take advantage of methanogenic bacteria (such as fatty acids, aromatic compounds, and ethanol), and those that do (where we find hydrogen, acetic and formic) (López et al., 2017). These compounds are also responsible for removing any trace of oxygen in the biodigester.

Acetogenesis: Any compound that could not be metabolized by methanogenic bacteria is used at this stage, and among them are aromatic, fatty acids and ethanol, which are transformed into others of less complexity, such as hydrogen and acetate (López et al., 2017). Homoacetogens also stands out here, a very particular type of acetogenic microorganism that is capable of generating acetate and is used to keep hydrogen gas below, since it does not produce it.

Methanogenesis: To complete the anaerobic decomposition of the products, methanogenic bacteria come into action, which is responsible for producing methane (López et al., 2017). It is known that $70 \%$ of the methane produced in biodigesters arises when acetic acid loses the carboxyl group of atoms since acetate can only be used by two genera of bacteria.

\section{Biogas production system and its life cycle}

Thanks to obtaining biogas, economic benefits derived from low-cost electric cogeneration are obtained. A general diagram of the biogas production process is shown in figure 4 considering four stages of its life cycle.

1) Manure

2) Production. Biogas production. Biogas

3) Transformation and use

4) Final disposal of organic fertilizer

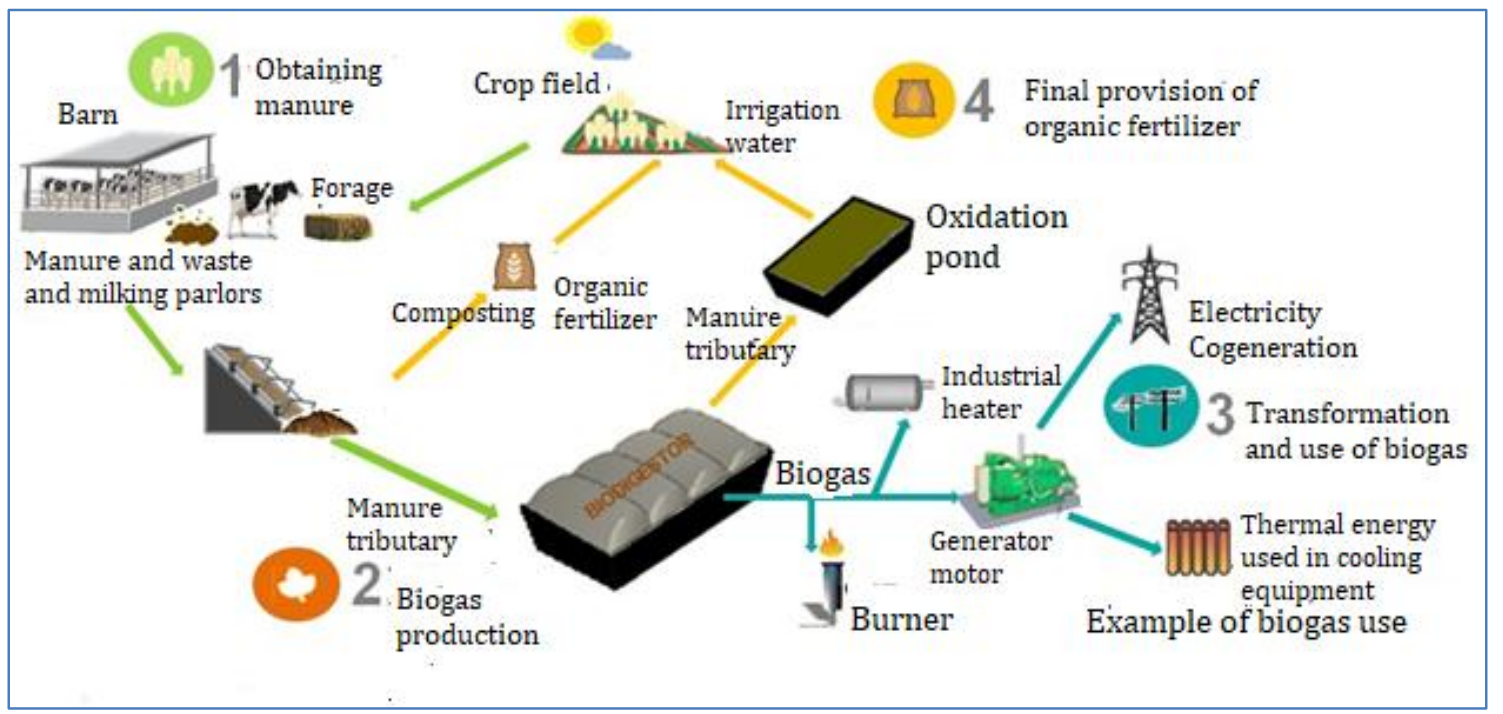

Figure 4. Life cycle and production system from Biogas

Source: (López et al., 2017)

Ecuador, being a country with great agricultural and livestock potential, and especially in Chone, you can obtain a large amount of organic waste (biomass) that can be used for The generation of alternative energies.

Mantuano, J. L. S., Macías, M. E. V., Toapanta, E. S. S., Palma, K. S. T., \& Giraldo, M. F. V. (2020). Obtaining biogas product from biological residues vaccines in Chone city. International Journal of Physical Sciences and Engineering, 4(1), 21-28. https://doi.org/10.29332/ijpse.v4n1.416 
However, the use of biogas for electric power generation is not a very common technology in our country. Biogas production has positive results, especially in low-income agricultural regions. The generation of biogas in the regions that take advantage of animal manure as one of the main sources of loading substrate for biodigesters has a better yield for obtaining biogas. The results of the analysis show that partial or total replacement of energy sources by biogas is feasible if the fermentation process is carried out under psychrophilic conditions (Yazdani \& Gonzalez, 2007; Han \& Shin, 2004; Kanca et al., 2017).

The concentration of greenhouse gases by human activity is considered the main cause of global warming. Livestock is responsible for $37 \%$ of all methane produced by human activity. In addition to this, cattle release greenhouse gases into the atmosphere by $18 \%$ from the digestion of cows worldwide, greater than transport. For this reason, the use of this organic matter is recommended as an economical and practical way of using it as an energy or calorific substitute using obtaining biogas. Cattle emit large amounts of methane, a gas that can now be used as alternative energy for domestic use and supplies energy to those places where conventional energy does not reach. A single head of cattle emits around 300 liters of methane per day, enough to generate energy and put into operation a refrigerator of about 100 liters of capacity at a temperature between two and six degrees for a full day.

\section{Conclusion}

Anaerobic fermentation is a natural biological process, in which a combustible gas or biogas and fertilizer waste are generated, which can be exploited for productive purposes. Biogas is a source of energy, economic and renewable, which must be developed in Ecuador to diversify the energy matrix and as a tool to mitigate environmental problems, which are lived today, and cease to be dependent on fossil fuels. The process for obtaining Biogas has positive impacts on the social, economic and especially environmental fields. This paper demonstrates the efficiency and viability of biogas as a source of energy, so it is important to promote its total implementation.

\section{Acknowledgments}

We thank all the authors for the collaboration, commitment, and enthusiasm they have shown for the realization of this article, as well as a special thanks from all the authors to Dr. Maria Rodriguez Gámez, tutor of the research, for having been a fundamental guide in the realization of it. In the same way, thanks to all the teachers of both the Technical University of Manabi and the Higher School of Polytechnic Agriculture of Manabí (ESPAM MFL) who collaborated, imparting their knowledge and recommendations for this research. 


\section{References}

Al Malki, A., Al Amri, M., \& Al Jabri, H. (1998). Experimental study of using renewable energy in the rural areas of Oman. Renewable Energy, 14(1-4), 319-324. https://doi.org/10.1016/S0960-1481(98)00084-6

Cadavid-Rodríguez, L. S., \& Bolaños-Valencia, I. V. (2015). Use of organic waste for the production of renewable energy in a Colombian city. Energetics, (46), 23-28.

Castillo, R. (2013). Added values of anaerobia biodigestión del jacinto de agua. University of cuenca, 1-116.

Díaz, P. (2013). Bioenergy in America. Organization of The United Nations For Food And, 1-431.

Durazno, A. (2018). Assessment of bovine and pig manure in the production of Biogas in a biodigestor of production in stages.

El-Ghonemy, A. M. K. (2012). Retracted: water desalination systems powered by renewable energy sources, Review. https://doi.org/10.1016/j.rser.2011.11.002

Garba, B. (1996). Effect of temperature and retention period on biogas production from lignocellulosic material. Renewable Energy, 9(1-4), 938-941. https://doi.org/10.1016/0960-1481(96)88434-5

Han, S. K., \& Shin, H. S. (2004). Biohydrogen production by anaerobic fermentation of food waste. International journal of hydrogen energy, 29(6), 569-577. https://doi.org/10.1016/j.ijhydene.2003.09.001

Jiménez, M. (2019). Defending animals goes beyond stopping eating meat. ElTelegrafo.

Kanca, I. N., Swadesi, I. K. I., Yoda, I. K., \& Wijaya, I. M. A. (2017). The effect of aerobic and anaerobic physical training on the absorptive cells, absorption of carbohydrate and protein in small intestine. International Research Journal of Engineering, IT \& Scientific Research, 3(6), 77-88.

Koroneos, C., Spachos, T., \& Moussiopoulos, N. (2003). Exergy analysis of renewable energy sources. Renewable energy, 28(2), 295-310. https://doi.org/10.1016/S0960-1481(01)00125-2

López, A., Hernández, O., \& Molina, V. (2017). Proposal for an efficient management process for the biogas production system for energy cogeneration in dairy farms in the Lagunera Region. Science, 1-17.

Macías, R. (2019). Chone Ecuador facts.

Martínez, M. (2015). Potential biogas production using pig cattle excreta in the state of Guanajuato. Scielo, $7(15)$.

Naundorf, E. A., Subramanian, D., Räbiger, N., \& Vogelpohl, A. (1985). Biological treatment of waste water in the compact reactor. Chemical Engineering and Processing: Process Intensification, 19(5), 229-233. https://doi.org/10.1016/0255-2701(85)80015-5

Paez, J. (2016). Design of a biodigester for waste management.

Portillo, G. (2017). The biogas. Source: Green Renewables

Rodriguez, M., Castillo, W., Vázquez, A., \& Saltos, W. (2016). Geographic location of the province of Manabí and the municipality Chone. . RIEMAT, 2(1), 1-6.

Serna, F., Barrera, L., \& Montiel, H. (2011). Social and Economic Impact on the Use of Biofuels. Scielo, 6(1).

Sharma, S. K., Mishra, I. M., Sharma, M. P., \& Saini, J. S. (1988). Effect of particle size on biogas generation from biomass residues. Biomass, 17(4), 251-263. https://doi.org/10.1016/0144-4565(88)90107-2

Sitorus, B., \& Panjaitan, S. D. (2013). Biogas recovery from anaerobic digestion process of mixed fruitvegetable wastes. Energy Procedia, 32, 176-182. https://doi.org/10.1016/j.egypro.2013.05.023

Sumathi, K. M. S., Mahimairaja, S., \& Naidu, R. (2005). Use of low-cost biological wastes and vermiculite for removal of chromium from tannery effluent. Bioresource technology, 96(3), 309-316. https://doi.org/10.1016/j.biortech.2004.04.015

Vera, I., Martínez, J., Estrada, M., \& Ortiz, A. (2014). Potential for generating biogas and electrical energy. Part I: excreta of cattle and pigs. Scielo, 15(3).

Yazdani, S. S., \& Gonzalez, R. (2007). Anaerobic fermentation of glycerol: a path to economic viability for the biofuels industry. Current opinion in biotechnology, 18(3), 213-219. https://doi.org/10.1016/j.copbio.2007.05.002

Mantuano, J. L. S., Macías, M. E. V., Toapanta, E. S. S., Palma, K. S. T., \& Giraldo, M. F. V. (2020). Obtaining biogas product from biological residues vaccines in Chone city. International Journal of Physical Sciences and Engineering, 4(1), 21-28. https://doi.org/10.29332/ijpse.v4n1.416 


\section{Biography of Authors}

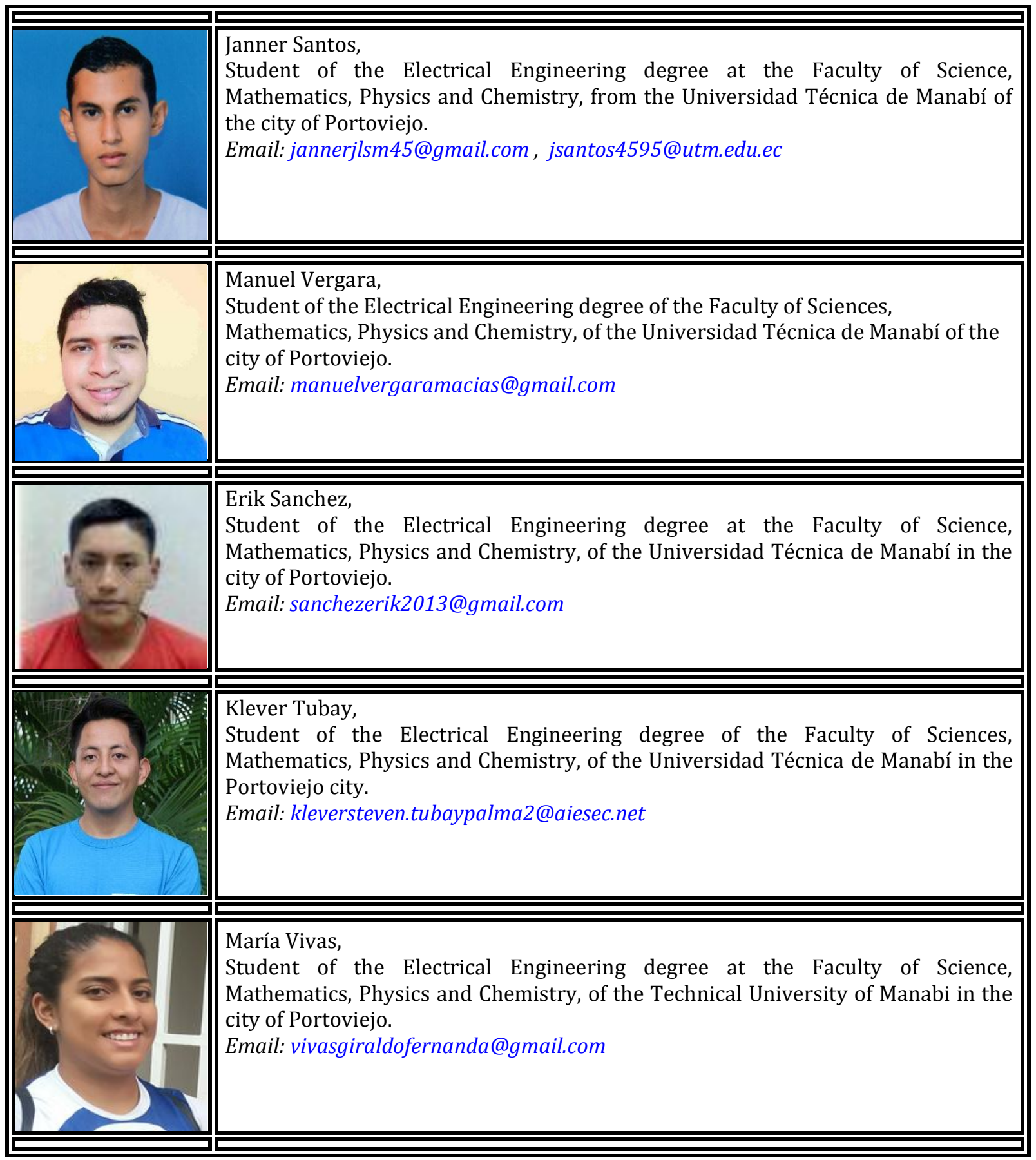

